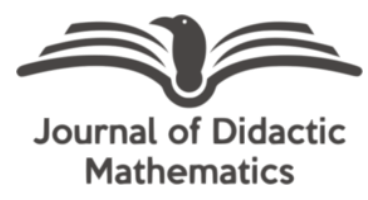

\title{
Penerapan multiple intelligence dalam pembelajaran matematika: Analisis pada kecerdasan musik
}

\section{Suwanto*}

STKIP Asy-Syafi'iyah Internasional Medan, Sumatera Utara, Indonesia, 20144

\section{Ade Evi Fatimah}

STKIP Al-Maksum, Stabat, Sumatera Utara, Indonesia, 28466

\section{Fitriani}

Universitas Muhammadiyah Tapanuli Selatan, Padangsidimpuan, Sumatera Utara, Indonesia, 22716

*Corresponding Author: suwantompd89@gmail.com

\begin{abstract}
Less optimal musical intelligence in students and improper application in mathematics learning is the basis for the preparation of articles. The misunderstanding of applying musical intelligence is quite alarming, for example when students learn to listen to music, they actually don't use their musical intelligence to learn or change their behavior. In this condition, music has a role in arousing motivation, memory and reflexes to learn, not using musical intelligence to learn. The preparation of this article uses the literature review method with the keywords musical intelligence (musical intelligence), learning and learning mathematics in books and journals indexed by Googles choolar. The application of musical intelligence in mathematics learning requires careful consideration and expertise in designing learning to be carried out. Some examples of using musical intelligence in learning mathematics include converting notes into numbers, solving math problems related to scales, designing memorization of mathematical formulas in the form of chants that are fun for students.
\end{abstract}

Historis Artikel:

Diterima: 20 November

2020

Direvisi: 26 November

2020

Disetujui: 27 Desember 2020

\section{Keywords:}

Multiple Intelligence;

Musical intelligence;

Mathematics learning

Sitasi: Suwanto., Fatimah, A. E., \& Fitriani. (2020). Penerapan multiple intelligence dalam pembelajaran matematika: Analisis pada kecerdasan musik. Journal of Didactic Mathematics, 1(3), 144-150. Doi: $10.34007 / j \mathrm{dm} . v 1 \mathrm{i} 3.445$.

\section{PENDAHULUAN}

Dalam kehidupan sehari-hari, hampir seluruh aktivitas yang dilakukan individu mmerlukan kombinasi beberapa kecerdasan (Fathani, 2016). Kecerdasan majemuk belum terintegrasi secara optimal dalam penyelenggara pendidikan di sekolah (Yaumi, 2012). Kemudian, dalam proses pembelajaran tidak semua kecerdasan majemuk dilibatkan oleh penyelenggara pendidikan. Kecerdasan yang sering dilibatkan dalam kegiatan pembelajaran selama ini hanyalah kecerdasan logis-matematis dan kecerdasan linguistik, sehingga siswa yang memiliki dan mengembangkan kecerdasan linguistik dan kecerdasan logis-matematis pasti akan berhasil dalam situasi sekolah tradisional (Jasmine, 2007). Selanjutnya para siswa dibiasakan untuk mengembangkan kecerdasan linguistik dan kemampuan logis-matematis, hal tersebut telihat dari instrumen yang sering digunakan(Gardner, 2013)

Kecerdasan logis-matematis sering dipandang dan dihargai lebih tinggi dari kecerdasan lainnya, khususnya dalam masyarakat teknologi dewasa ini (Jasmine, 2007). Dalam melakukan proses pendidikan yang menekankan pada perbaikan aktivitas pembelajaran yang terfokus pada pengembangan kecerdasan majemuk (multiple Intelligence) sangat dibutuhkan (Yaumi, 2012). Atas dasar inilah sangat perlu dikaji teori-teori kecerdasan majemuk terhadap pembelajaran dalam hal 
Penerapan multiple intelligence dalam pembelajaran matematika...

ini pembelajaran matematika. Bagaimana dengan kecerdasan musik? dan bagaimana menerapkannya dalam pembelajaran matematika? Maka dalam artikel ini akan di bahas bagaimana menerapkan kecerdasan musik siswa pada saat pembelajaran matematika. Saat belajar matematika, kecerdasan logic matematic sangat mendukung siswa dalam memahami matematika, sedangkan untuk kecerdasan yang lain bagaimana? Apakah harus diabaikan dan tutup mata terhadap kecerdasan yang lain. Dimana letak keunikan peserta didik, jika saat belajar matematika semua dianggap sama.

Penerapan teori kecerdasan majemuk, kadang masih diftafsirkan berbeda dengan teori yang sebenarnya, yang menjadi lebih prihatin lagi adalah kesalahan penerapan metode pembelajaran berbasis multiple inteeligence pada pembelajaran matematika. Misalkan siswa dengan kecerdasan musical yang pekak dengan indra pendengarannya (Elfiadi, 2017; Rosydiana, 2017; Setiawan, 2020), didengarkan music saat kegiatan belajar matematika belangsung, manakah yang didengarkannya, penjelasan atau musik? Atau musik justru menganggu proses pembelajaran karena dianggap berisik (Roffiq et al., 2017), berisik sendiri dapat menggangu konsentrasi belajar siswa (Halil et al., 2015). Pemutaran musik (Snyder, 1997), permainan musik (Prasetya et al., 2017), dan bernyanyi (Elfiadi, 2017) dapat meningkat kecerdasan musik anak. Pemutaran musik saat belajar merupakan wujud dari penerapan kecerdasan musik (Susanto, 2005), namun tidak hanya sebatas memutarkan musik saja (Serani, 2019). Sehingga muncul pertanyaan dalam pembelajaran matematika kaitannya dengan penerapan kecerdasan musik, sebaiknya musik itu didengarkan, dimainkan, atau dinyanyikan?

\section{METODE}

Metode yang digunakan dalam menulisan artikel ini adalah literatur review, yakni sebuah pencarian literatur yang berasal dari buku dan jurnal yang terindeks Google schoolar yang terbit dalam kurun waktu 20 tahun terakhir. Pencarian pada laman Google Schoolar menggunakan kata kunci kecerdasan majemuk (mulitple intelligence), kecerdasan musik (musical intelligence), belajar dan pembelajaran matematika dan teori belajar matematika.

\section{HASIL DAN PEMBAHASAN}

Kecerdasan adalah kemampuan yang terdiri dari tiga komponen, yakni (1) kemampuan untuk mengarahkan pikiran atau tindakan, (2) kemampuan untuk mengubah arah pikiran atau tindakan, dan (3) kemampuan untuk mengkritisi pikiran dan tindakan diri sendiri atau autocritism. Sedangkan Multiple intelligences atau biasa disebut dengan kecerdasan majemuk adalah berbagai keterampilan dan bakat yang dimiliki siswa untuk menyelesaikan berbagai persoalan yang dihadapinya.

Pencetus teori kecerdasan majemuk (multiple intelligence) adalah Howard Gardner pada tahun 1983, menemukan tujuh kecerdasan majemuk saja diantaranya: (1) kecerdasan musik; (2) kecerdasan kinestetik tubuh; (3) kecerdasan logis matematis; (4) kecerdasan linguistik; (5) kemampuan spasial; (6) kemampuan interpersonal; dan (7) kemampuan intrapersonal. Dalam perkembangannya teori kecerdasan majemuk mengalami penambahan kecerdasan diantaranya kecerdasan naturalistik dan kecerdasan eksistensial. Bagaimana siswa belajar dan memahami sesuatu dengan menggunakan kecerdasan yang mereka memiliki sangatlah unik untuk pelajari. Salah satu kecerdasan yang perlu dikembangkan adalah kecerdasan musik, dimana kecerdasan ini berkembang lebih awal dan bertahan lama sampai tua (Rofiah, 2016)

Karakter kecerdasan musik adalah kapasitas untuk berpikir tentang musik, seperti mampu mendengar, mengenal, mengingat, dan bahkan memanipulasi pola-pola musik (Yaumi, 2012). Kemudian kemampuan musik adalah kemampuan untuk memahami dan mengekspresikan komponen musik, termasuk pola melodi maupun ritme, melalui cara-cara figural atau intuitif atau melalui cara-cara formal (Amstrong, 2014). Kecerdasan musikal merupakan kemampuan berfikir untuk mencerna, menyimak pola-pola, mengenalinya, mengubah komposisi dan memanipulasi musik (Suarca et al., 2005; Yuwono, 2016). Untuk mengembangkan kecerdasan musical dapat dilakukan dengan berbagai cara memperkenalkan, mendengarkan musik dan membuat instrumental musik di kelas (Campbell, 2001) serta diskografi dan bunyi (Yaumi \& Ibrahim, 2013). 
Memainkan perkusi sederhana (Yeni, 2015) Piano, Angklung, Seruling dan suara seseorang (Fatonah, 2017) dapat mengembangkan kecerdaan musik anak,

Orang yang memiliki kecerdasan musik adalah orang yang mempunyai kecerdasan jenis ini sangat peka terhadap suara atau bunyi, lingkungan dan juga musik (Jasmine, 2007). Mereka sering bersiul atau bersenandung ketika melakukan aktivitas lain. Orang yang memiliki kercerdasan musik dianggap memiliki apresiasi yang kuat terhadap musik, dengan mudah mengingat lagu-lagu dan melodi, mempunyai pemahaman tentang warna nada dan komposisi, dapat membedakan antara pola nada dan pada umumnya senang terbenam dalam musik (Yaumi, 2012).

Orang yang unggul dalam kecerdasan musik tentunya dapat dibedakan dengan orang yang memiliki kecerdasan yang lain, baik dari ciri-ciri maupun karakteristik. Ciri dan karakteristik kecerdasan musik dapat dijabarkan sebagai berikut: (1) sangat tertarik untuk memainkan instrumen musik; (2) merasa mudah belajar dengan pola-pola dengan irama musik; (3) selalu terfokus yang berkaitan dengan suara dan bunyi-bunyi; (4) berpindah-pindah sambil memukul-mukul sesuatu seperti meja, kursi, tembok dan benda-benda yang ada di sekitar; (5) intonasi suara pada saat membaca sangat mengesankan; (6) sangat mudah menghafal dan mengingat ketika objek yang dihafal atau dibaca dimasukkan ke dalam irama-irama musik; (7) mengalami kesulitan untuk berkonsentrasi ketika mendengar suatu radio dan televisi; (8) sangat senang menikmati semua jenis musik dan lagu; (9) merasa bahwa irama musik jauh lebih menarik daripada melakukan atau bermain sesuatu; (10) dapat meningat lagu sekaligus liriknya lebih mudah jika dibandingkan mengingat informasi yang lain (Yaumi, 2012).

Belajar adalah suatu proses usaha yang dilakukan seseorang untuk memperoleh perubahan tingkah laku yang baru secara keseluruhan, sebagai hasil pengalamannya sendiri dalam interaksi dengan lingkungannya (Slameto, 2010). Jadi dapat dikatakan bahwa belajar merupakan suatu proses usaha yang dilakukan secara sadar oleh seorang individu untuk menghasilkan suatu perubahan yang mencakup seluruh aspek tingkah laku, dimana perubahan tersebut dapat diamati, bersifat kontinue, fungsional, positif dan aktif yang berlangsung dalam waktu yang relatif lama.

Belajar dan pembelajaran merupakan suatu hal yang tidak dapat dipisahkan. Belajar merupakan proses internal siswa dan pembelajaran merupakan kondisi eksternal belajar. Dari segi siswa, belajar merupakan kegiatan peningkatan kemampuan kognitif, afektif, dan psikomotorik menjadi lebih baik, dan dari segi guru, belajar merupakan akibat dari tindakan pembelajaran (Dimyati \& Mudjiono, 2006). Kemudian lebih dalam lagi pembelajaran matematika adalah suatu upaya/kegiatan (merancang dan menyediakan sumber-sumber belajar, membantu/membimbing, memotivasi, mengarahkan) dalam membelajarkan siswa untuk mencapai tujuan pembelajaran matematika, yaitu: belajar bernalar secara matematis, penguasaan konsep dan terampil memecahkan masalah, belajar memiliki dan menghargai matematika sebagai bagian dari budaya, menjadi percaya diri dengan kemampuan sendiri, dan belajar berkomunikasi secara matematis.

Dalam berpikir, seseorang dapat menyusun hubungan-hubungan antar bagian-bagian informasi sebagai pengertian, kemudian dapat disusun kesimpulan (Hudojo, 1988). Dalam proses belajar mengajar matematika terjadi proses berpikir. Seseorang dikatakan berpikir apabila melakukan kegiatan mental dan orang yang belajar matematika selalu melakukan kegiatan mental. Dari sini terlihat bahwa belajar matematika itu merupakan proses membangun atau mengkonstruksi konsep-konsep dan prinsip-prinsip tidak sekedar penghafalan yang terkesan pasif dan statis, akan tetapi belajar itu harus aktif dan dinamis. Kaitannya dengan kecerdasan musik, cara kerja otak memahami musik sama dengan cara kerja otak menyelesaikan soal matematika (Rachmi, 2013). Bukti nyatanya adalah dengan bermain musik dapat membantu menyeimbangkan otak kiri dan otak kanan, dan musik klasik juga sangat mempengaruhi perkembangan IQ (Intelegent Quotien) dan EQ (Emotional Quotien) (Roffiq et al., 2017)

Dalam menerapkan kecerdasan musik pada pembelajaran matematika, seorang guru harus kolaborasikan antara tujuan pembelajaran matematik, lingkungan sekolah, kecerdasan majemuk dan berbagai macam metode pembelajaran (Fatonah, 2017). Untuk menrancang pembelajaran 
Penerapan multiple intelligence dalam pembelajaran matematika...

seperti ini keprofesionalan seorang guru sangat dituntut. Salah satu caranya memecahkan teka-teki musik seperti pada gambar di bawah ini.

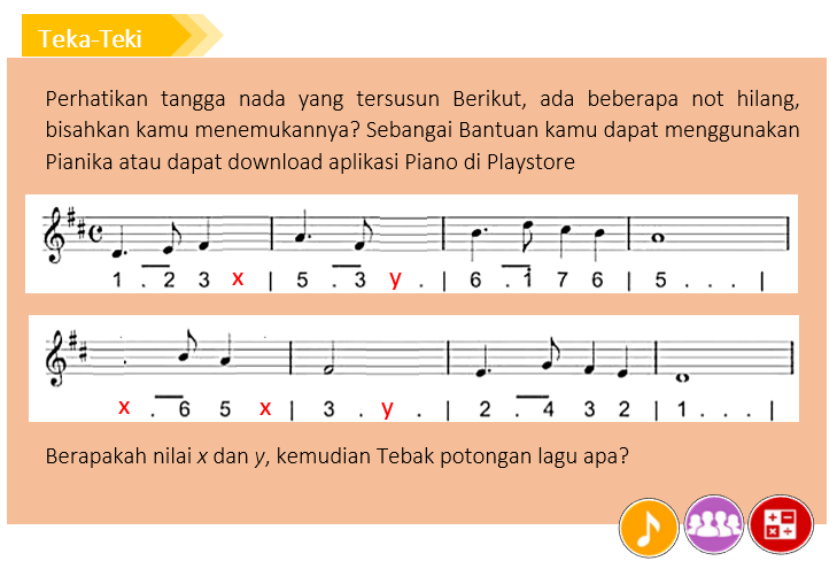

Gambar 1. Teka-Teki yang memanfaatkan kecerdasan musik

Dengan memainkan not di atas melalui alat musik seperti Pianika, atau Aplikasi Piano yang dapat diakses melalui Android mereka, mereka diminta untuk menemukan nilai $x$ dan $y$. Saat proses pencarian tangga nada ' $x$ ' dan ' $y$ ' kecerdasan musik sangat dibutuhkan untuk menyelesaikan tekateki tersebut. Namun tidak cukup hanya menemukan $x$ dan $y$ saja, perlu lanjutkan pada pemecahan masalah selanjutnya, seperti meminta mereka menentukan ' $x^{2}+y^{2}+20$ ' atau dengan memanfaatkannya untuk yang lain. Jika hanya sampai pada menemukan $x$ dan $y$ hanya meningkatkan kecerdasan musik saja dan hanya meningkatkan motivasi belajar siswa saja, namun tidak memberikan dampak berarti pada pembelajaran matematika yang bermakna. Jika terbatas dengan alat musik, maka pengajar dapat menggunakan alat lain seperti kaleng, meja atau alat lain yang dapat menghasilkan suara unik, yang nantinya suara itu akan menjadi kode angka-angka yang digunakan dalam operasi matematika. Namun pemilihan suara tetap mempertimbangkan kenyamanan siswa, jika suara tersebut tidak nyaman maka hal tersebut dianggap sebuah kebisingan baginya (Barrientos et al., 2014).

Untuk mendukung pembelajaran berbasis multiple intelligences maka diperlukan pembelajaran yang lebih bervariatif. Penerapan kecerdasan majemuk dalam pembelajaran tidak hanya satu cara, teori kecerdasan majemuk ini fleksibel (Gasm \& Ahmed, 2012). Pembelajaran yang mendukung pembelajaran berbasis multiple intelligence yaitu model pembelajaran kooperatif, karena dengan pembelajaran kooperatif, siswa akan mampu mengoptimalkan kecerdasan yang dimilikinya seperti misalnya pada kecerdasan yang mengaharuskan terjadi hubungan sosial diantara peserta didik (Wahyuni \& Pramukantoro, 2014). Oleh karena itu perlu dibentuk belajar kooperatif agar siswa dapat bekerjasama dalam kelompok dan diharapkan dengan kemampuan yang berbeda-beda tersebut, siswa yang lebih pintar dapat mengajari siswa yang kurang pintar. Penerapan pembelajaran kooperatif dengan melibatkan semua kecerdasan majemuk akan memberikan wawasan baru dalam menyelesaikan masalah berdasarkan masing-masing cara dan karakteristik kecerdasan majemuk (Abdulkarim \& Jadiry, 2012). Sehingga siswa yang satu dengan siswa yang lain akan saling memberikan cara baru berdasarkan pengalaman dan kecerdasan yang dimiliki siswa.

Pembelajaran kooperatif secara aktif melibatkan kecerdasan interpersonal. Mengajar siswa untuk bekerjasama dengan baik dengan orang lain, mendorong kolaborasi (kerjasama), berkompromi, dan bermusyawarah mencapai kesepakatan; dan secara umum menyiapkan mereka untuk dunia hubungan personal dan bisnis sebenarnya (Jasmine, 2007). Pada bidang sains dan bidang lain pembelajaran kooperatif berdasarkan kecerdasan majemuk mempunyai pengaruh dan perlu mengeksplotasinya lebih dalam (Abdulkarim \& Jadiry, 2012).

Teori belajar kontruktivisme dan teori belajar Vygotsky merupakan dasar teori untuk menerapkan kecerdasan majemuk (multiple intelligence) dalam permbelajaran matematika. Teori 
belajar konstruktivisme merupakan suatu aktivitas yang berlangsung secara interaktif antara faktor internal pada diri pebelajar dengan faktor eksternal atau lingkungan, sehingga melahirkan perubahan tingkah laku (Iskandar, 2009). Salah satu faktor internal adalah kecerdasan majemuk. Untuk menyesuaikan bidang matematika terhadap musik memang sulit, tetapi hal itu bukan hal yang tak mungkin. Kita dapat merumuskan konten matematika dalam bentuk nyanyian yang menjadi hafalan sementara peserta didik, karena dengan bernyanyi dapat mempengaruhi dan mengendalikan pusat syaraf (Widhianawati, 2011). Tetapi hafalan lagu/nyanyian tersebut harus dibarengi oleh praktik, bukan hanya sekedar menghafal.

Kemudian cara yang lain kita dapat mengkonversi angka-angka matematika dalam bentuk not nada, memang hal ini akan terasa canggung untuk peserta didik yang tidak minat terhadap musik. Oleh karena itu kepiawaian guru dalam mendesain pembelajaran sangat dibutuhkan. Tidak hanya bunyi not saja yang digunakan, bunyi-bunyi yang lain juga dapat digunakan dalam menerapkan kecerdasan musik dalam pembelajaran matematika seperti, bunyi ketukkan meja, kursi, kaleng dan lain sebagainya. Dan guru dapat menrancang masalah yang dalam pemecahannya butuh suara-suara yang unik atau lagu untuk ditebak.

Untuk membantu kefokusan individu, mengizin mereka untuk mendengarkan musik ketika belajar dapat menjadi solusinya (Amstrong, 2014) musik juga dapat mencitapkan kegairahan, relaksasi dan pembangkit motivasi siswa dalam belajar (Halimah, 2010). Pemutaran musik klasikal dapat meningkatkan hasil belajar matematika (Prakoso et al., 2017) dan juga kemampuan bahasa (Rachmi, 2013). Hal ini bukan karena siswa menggunakan kecerdasan musiknya untuk meningkatkan hasil belajarnya melainkan dikarenakan musik klasikal mempengaruhi kerja otak siswa (Musbikin, 2009; Satiadarma \& Zahra, 2004; Sheppard, 2007).

\section{KESIMPULAN}

Dalam penerapkan kecerdasan musik, dapat menjadikan musik untuk diputarkan atau didengarkan kepada siswa saat mereka tidak melakukan aktivitas belajar yang membutuhkan konsentrasi penuh, jadi musik dapat diputarkan pada saat mereka istrihat atau pada saat awal dimulai pembelajaran guna untuk membangkitkan motivasinya. Musik dapat dimainkan oleh siswa atau guru di saat pelaksanaan pembelajaran matematika, namun kehadiran musik di sini sebagai alat pendukung pembelajaran untuk memecahkan masalah atau soal yang diberikan oleh guru. Kemudian dengan mengaitkan pembelajaran matematika, siswa dapat menciptakan lagu yang akan dinyanyikan untuk menjadi sarana menghafal formula siswa, namun jangan hanya sebatas menghafal saja perlu dilakukan pengaplikasian formula yang dinyanyikan.

\section{DAFTAR PUSTAKA}

Abdulkarim, R., \& Jadiry, A. Al. (2012). The effect of cooperative learning group division based on multiple intelligences theory and previous achievement on scientific thinking skills development of ninth grade students in Oman. European Journal of Social Sciences, 27(4), 553569.

Amstrong, T. (2014). Kecerdasan Jamak dalam Membaca dan Menulis Membuat Kata-Kata Menjadi Lebih Hidup. Indeks.

Barrientos, M. C., Lendrum, D. C., \& Steenland, K. (2014). Assessing the burden of disease from work-related hearing impairment at national and local levels. In A. P. Ustun, D. C. Lendrum, C. Carvalan, \& A. Woodward (Eds.), Occupational noise Assessing (Issue 9, pp. 1115-1122). World Health Organization. https://doi.org/10.1002/9781118834015.ch104

Campbell, D. (2001). Efek Mozart, memanfaatkan Kekuatan Musik untuk Mempertajam Pikiran,Meningkatkan Kreativitas, dan Menyehatkan Tubuh. Gramedia.

Dimyati, \& Mudjiono. (2006). Belajar dan Pembelajaran. Rineka Cipta.

Elfiadi. (2017). Kecerdasan jamak pada anak usia dini. Itqan, 8(2), 35-52.

Fathani, A. H. (2016). Rahmah Johar. "Domain Soal PISA untuk Literasi matematikaa". Jurnal Peluang, Volume 1, Nomor 1, Oktober 2012. 136. Jurnal EduSains, 4(2), 136-150. 
Penerapan multiple intelligence dalam pembelajaran matematika...

Fatonah, S. (2017). ( Multiple Intelligence ) Anak Dengan Men Genal Gaya Belajarnya. Psikologi Pendidikan, 1, 229-246.

Gardner, H. (2013). Multiple Intelligence/Howard Gardner (Yelvi (ed.)). Daras Books.

Gasm, A., \& Ahmed, A. (2012). The Relation between Multiple Intelligences Theory and Methods of ELT. International Journal of Learning and Teaching, 4(2), 26-41. www.awer-center.org/ijlt

Halil, A., Yanis, A., \& Noer, M. (2015). Pengaruh Kebisingan Lalulintas terhadap Konsentrasi Belajar Siswa SMP N 1 Padang. Jurnal Kesehatan Andalas, 4(1), 53-57. https://doi.org/10.25077/jka.v4i1.188

Halimah, L. (2010). Musik dalam Pembelajaran. Edubumaniora, Jurmal Pendidikan Dasar, 2(2).

Hudojo, H. (1988). Mengajar Belajar Matematika. Depdikbud.

Iskandar. (2009). ) Psikologi Pendidikan Sebuah Orientasi Baru. Gaung Persada (GP) Press.

Jasmine, J. (2007). Panduan Praktis Mengajar Berbasis Multiple Intelligences. Nuansa.

Musbikin, I. (2009). Kehebatan Musik untuk. Mengasah Kecerdasan Anak. Powerbooks Publisher.

Prakoso, Y. Al, Hannifah, H., \& Maizora, S. (2017). Pengaruh Musik Klasik Terhadap Hasil dan Aktivitas Belajar Matematika Siswa Kelas VII di SMPN 2 Kota Bengkulu. Jurnal Penelitian Pembelajaran Matematika Sekolah (JP2MS), 1(1), 26-35. https://doi.org/10.33369/jp2ms.1.1.26-35

Prasetya, Y. O., Chulwah, D., Mubarokah, N. L., \& Iswantiningtyas, V. (2017). Pengaruh Bermain Sianida (Suara, Irama, Dan Nada) Terhadap Kecerdasan Musik Anak Usia Dini. JURNAL INDRIA Jurnal Ilmiah Pendidikan Prasekolah Dan Sekolah Awal), 2(2), 68-79. https://doi.org/10.24269/jin.v2n2.2017.pp56-67

Rachmi, T. (2013). Kontribusi Musik pada Perkembangan Anak Usia Dini. Jakarta: Universitas Terbuka, 1-29. http://www.pustaka.ut.ac.id/lib/wp-content/uploads/pdfmk/PAUD4402M1.pdf

Roffiq, A., Qiram, I., \& Rubiono, G. (2017). Media Musik Dan Lagu Pada Proses Pembelajaran. JPDI (Jurnal Pendidikan Dasar Indonesia), 2(2), 35. https://doi.org/10.26737/jpdi.v2i2.330

Rofiah, N. H. (2016). Menerapkan multiple intelligences dalam pembelajaran di sekolah dasar. Jurnal Dinamika Pendidikan Dasar, 8(1), 69-79. https://doi.org/10.30595/dinamika.v8i1.937

Rosydiana, E. (2017). Meningkatkan Kecerdasan Musik melalui Permainan Angklung di PAUD Aulia. Yaa Bunayya: Jurnal Pendidikan Anak Usia Dini, 1(2), 53-64.

Satiadarma, M. P., \& Zahra, R. P. (2004). Cerdas Dengan Musik. Puspa Swara.

Serani, G. (2019). Euretmika Dalcroze Dan Relevansinya Bagi Pengembangan Kecerdasan Musikal Anak Di Paud. Dunia Anak: Jurnal Pendidikan Anak Usia Dini, 2(2), 60-75. https://doi.org/https://doi.org/10.31932/jpaud.v2i2.766

Setiawan, A. R. (2020). Kecerdasan Majemuk Berdasarkan Neurosains Multiple Intelligences Based on Neuroscience. Kajian Keilmuan, 1(1), 1-8.

Sheppard, P. (2007). Music Makes Your Child Smarter: Peran Musik dalam Perkembangan Anak. Gramedia Pustaka Utama.

Slameto. (2010). Belajar dan Faktor-Faktor yang Mempengarubi. Rineka Cipta.

Snyder, S. (1997). Developing musical intelligence: Why and How. Early Childhood Education Journal, 24(3), 165-171. https://doi.org/10.1007/BF02353274

Suarca, K., Soetjiningsih, S., \& Ardjana, I. E. (2005). Kecerdasan Majemuk pada Anak. Sari Pediatri, 7(2), 8592. https://doi.org/10.14238/sp7.2.2005.85-92

Susanto, H. (2005). Penerapan Multiple Intelligences dalam Sistem Pembelajaran. Jurnal Pendidikan Penabur, 4(4), 67-75.

Wahyuni, S., \& Pramukantoro, J. A. (2014). Perbandingan Model Pembelajaran Kooperatif Berbasis Multiple Intelligences Dengan Pembelajaran Kooperatif Tipe STAD Terhadap Hasil Belajar Siswa Pada Standar Kompetensi Memahami Dasar-Dasar Kelistrikkan di SMK Negeri 3 Surabaya. Jurnal Pendidikan Teknik Elektro, 3(1), 245-252.

Widhianawati, N. (2011). Pengaruh pembelajaran gerak dan lagu dalam meningkatkan kecerdasan musikal dan kecerdasan kinestetika anak usia dini. Academia.Edu, 2(Edisi Khusus), 220-228. 
http://www.academia.edu/download/34063262/22-nana_widhianawati-bl.pdf

Yaumi, M. (2012). Pembelajaran Berbasis Multiple Intelligences. Dian Rakyat.

Yaumi, M., \& Ibrahim, N. (2013). Pembelajaran Berbasis Kecerdasan Jamak (Multiple Intelligences) Mengidentifikasi dan Mengembangkan Multitallenta Anak. In Muhammad (Ed.), Kencana (3rd ed.). Prenadamedia Group.

Yeni, I. (2015). Keefektifan Penggunaan Permainan Perkusi Sederhana Untuk Meningkatkan Kecerdasan Musikal Anak Di Taman Kanak-Kanak. Jurnal Pendidikan Dan Pembelajaran Universitas Negeri Malang, 22(1), 76-81.

Yuwono, P. H. (2016). Pengembangan Intelegensi Musikal Siswa Melalui Pembelajaran Musik Di Sekolah. Khazanah Pendidikan: Jurnal Ilmiah Kependidikan, 10(1), 25-38. 